Click www.researchjournal.co.in/online/subdetail.html to purchase.

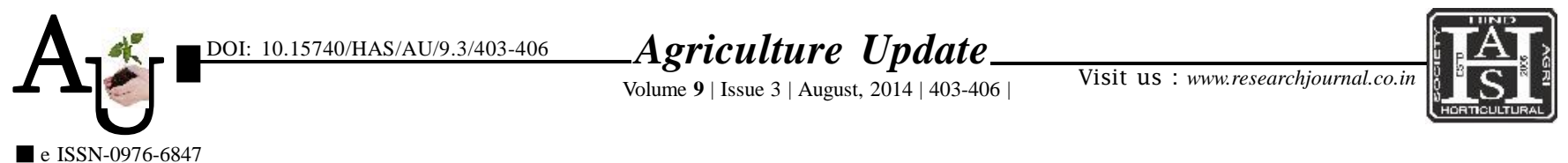

\title{
Research Article Constraints faced by sweet orange growers while adopting recommended package of practices
}

\author{
C.L. BHANDARE, V.B. KAMBLE AND V.N. SIDAM
}

Article Chronicle: Summary : A study was conducted to determine the constraints being faced by farmers in adoption of Received :

22.03.2013;

Revised :

03.07.2014;

Accepted :

14.07.2014 recommended package of practices of sweet orange growers faced constraints in cultivation practices like soil, plantation, training and pruning, intercultural operation, irrigation, fertilizer, pesticides, withholding of water, harvesting and post harvesting and price for fruits. With help of following objective : to ascertain the constraints faced by sweet orange growers while adopting recommended package of practices. This study was carried out in Aurangabad district of Marathwada region of Maharashtra during 2011 in two selected blocks. 120 randomly selected farmers who ware practicing sweet orange cultivation.

How to cite this article : Bhandare, C.L., Kamble, V.B. and Sidam, V.N. (2014). Constraints faced by sweet orange growers while adopting recommended package of practices. Agric. Update, 9(3): 403-406.

KeY Words :

Constraints,

Adoption,

Sweet orange

grower

Author for correspondence :

\section{C.L. BHANDARE}

Department of

Extension Education,

Vasantrao Naik

Marathwada Krishi

Vidypeeth, PARBHANI

(M.S.) INDIA

See end of the article for

authors' affiliations 